\title{
Az Egyetemes Tizedes Osztályozás húsz éve*
}

\section{Bevezetés}

Az Egyetemes Tizedes Osztályozás (ETO) az egyik legrégebbi, napjainkban is használt általános célú osztályozási rendszer. 1895-ben hozta létre Paul Otlet, Melvil Dewey decimális osztályozásának kiterjesztésével. Az ETO hierarchikus természete Dewey mereven hierarchikus osztályzásának öröksége, ugyanakkor az Otlet által bevezetett alosztások rendszerének köszönhetően ez volt a világ első analitikus-szintetikus, fazettás jellegü osztályozási rendszere. ${ }^{12}$

Miután a rendszer létrehozása óta eltelt száz év osztályozástudományi és informatikai kutatásai rávilágítottak, hogy a hatékony információkeresés a rendszer automatizációját és fazettás jellegének erősítését igényli, a Nemzetközi Dokumentációs Szövetség (International Federation for Information and Documentation, FID) 1992-ben átadta az ETO-val kapcsolatos jogait és feladatait egy nonprofit konzorciumnak (UDC Consortium, UDCC), amely vállalta, hogy a rendszer tartalmi aktualizálása mellett szisztematikusan átdolgozza azt fazettás alapokon, a gépesítés megkönnyítését is szem elött tartva. Létrehozták a további kiadások és a karbantartások alapját képező ETO mesterfile-t (Master Reference File, MRF), és a legfrissebb változásokat évröl évre közreadják az Extensions and Correctionstothe UDC (EC) címü kiadványban. ${ }^{3}$

A még mindig széles körben használt, 1990. évi (1991-ben újra kiadott) magyar nyelvű ETO középkiadás ${ }^{4}$ még a fenti változások és a szisztematikus fazettás revízió megkezdése előtt jelent meg, 1992-ben pedig a teljes magyar nyelvü ETO köteteinek a kiadása is véget ért. ${ }^{5} \mathrm{~A}$ legutóbbi nyomtatott magyar kiadás a 2000

*A tanulmány megírásához nyújtott segítségükért szeretnék köszönetet mondani Dancs Szabolcsnak és Aida Slavicnak.

${ }^{1}$ Slavic, Aida - Davies, Sylvie: Facet Analysis in UDC: Questions of Structure, Functionality and Data Formality. $=$ Knowledge Organization, 44. vol. 2017. 425-435. p.

${ }^{2}$ McIlwaine, I. C.: The Universal Decimal Classification: Some Factors Concerning Its Origins, Development, and Influence. $=$ Journal of the American Society for Information Science, 48. vol. 1997. 331-339. p.

${ }^{3}$ Slavic, Aida - Cordeiro, Maria Inês - Riesthuis, Gerhard: Maintenance of the Universal Decimal Classification: overview of the past and preparations for the future. $=$ International Cataloguing and Bibliographic Control, 37. vol. 2008. 2. no. 23-29. p.

${ }^{4}$ Országos Műszaki Információs Központ és Könyvtár (OMIKK) - Országos Széchényi Könyvtár Könyvtártudományi és Módszertani Központ (OSZK-KMK): Egyetemes tizedes osztályozás. Rövidített kiadás. Budapest, OMIKK, OSZK-KMK. 1990. 388. p.

${ }^{5}$ Barátné Hajdu Ágnes: A magyar ETO-kiadás munkálatai. = Könyv, Könyvtár, Könyvtáros, 16. évf. 2007. 2. sz. 20-39. p. 
decemberében kiadott Extensions and Corrections 22 anyagát tartalmazza, ${ }^{6}$ bár az elhúzódó munkálatok miatt nálunk csak 2005-ben jelent meg. 2018 végén az Országos Széchényi Könyvtár teljes jogú tagként csatlakozott a UDCC-hez, és 2019-ben az új magyar fordítás előkészítése is elkezdődött. Tervek szerint az új, nyomtatott kötet kiadása helyett az állomány a Magyar Nemzeti Névtérbe $^{7}$ lesz feltöltve, kiaknázva a kapcsolt adat (linked data) technológia elönyeit, rugalmas hozzáférést biztosítva az állományhoz mind a felhasználók, mind a szerkesztők számára. ${ }^{8}$

Bár a szisztematikus revízió számos eredménye már megjelent a 2005. évi magyar kiadásban, az azóta eltelt húsz év számos további újítást hozott. Jelen cikkben ezeket a változásokat igyekszem bemutatni.

\section{A revízió jellege}

A fazetta-analízis során a fogalmak kölcsönösen kizáró kategóriák szerint kerülnek felbontásra, ahol minden kategória külön hierarchiát képvisel. A fazettaanalízis történhet intuitív módon vagy a formális logika elvei alapján, továbbá oly módon is, hogy a fazetták típusának meghatározása és kiválasztása az általános kategóriák típusát, számát és sorrendjét meghatározó előre lefektetett elméleti keretrendszer szerint történik. Az ilyen elveket Fazetta-Analízis Elméletnek (Facet Analitical Theory, FAT) nevezzük. ${ }^{9}$

Az ETO-ban, mivel kialakulása jóval megelőzte a fazetta-analízis tudományos vizsgálatát, eredetileg tipikusan az intuitív fazetta-alkotás a jellemző. A szisztematikus, az adott terület elemzése alapján kidolgozott FAT-revízió legtöbbet idézett példája a rendszerben a 2 Vallás. Teológia föosztály teljes fazettás átszervezése $^{10}$, de ide sorolható a 80 Nyelvtudomány, 81 Nyelvészet és 82 Irodalom osztályok revíziója is. ${ }^{11}$ Bár ezekre az átszervezésekre jellemző, hogy az alkalmazott kategóriák listája és a megjelenési módjuk is tudományterületenként és alkalmanként változik, általában igyekeznek a terület egészén értelmezhető jellemzőket megragadni. Az általánosan elterjedt megoldás szerint ezeket a jellemzőket a vonatkozó osztály vagy fóosztály meghatározásánál sorolják fel

${ }^{6}$ Országos Széchényi Könyvtár Könyvtári Intézet (OSZK KI): Egyetemes tizedes osztályozás. 1. kötet: Táblázatok 1-2. rész. UDCC Publication P057. Budapest, Országos Széchényi Könyvtár Könyvtári Intézet. 2005. 536+554. p.

${ }^{7}$ http://abcd.hu (2019. október 1.)

${ }^{8}$ Piros Attila: Hogyan tovább, ETO? Fórum az ETO jövőjéről. = Könyv, Könyvtár, Könyvtáros, 27. évf. 2018. 6. sz. 3-10. p.

${ }^{9}$ Slavic, Aida - Davies, Sylvie: i. m.

${ }^{10}$ A nyolcas főosztály fazettás revíziójának eredménye 1992-ben (EC 14 [1]), a vallásé 2000ben (EC 22) lett publikálva, így mindkét osztály már az átdolgozott formájában jelent meg a 2005-ös magyar kiadásban.

${ }^{11}$ Slavic, Aida - Davies, Sylvie: i. m. 
korlátozottan közös alosztásként, felszámolva a specifikusabb, csak az alacsonyabb hierarchiaszintekre vonatkoztatható alosztásokat. ${ }^{12}$

Szintén a szintetikus szemlélet hatása, hogy az adatbázisban az olyan hagyományos mezők, mint a jelzet, a megnevezés, a hatókör (Scope note, SN) szemantikai kapcsolatai mellett fontos szerephez jutnak az alkalmazásra vonatkozó megjegyzések (Application note, $\mathrm{AN}$ ) és a kombinációs példák (Examples of Combination, EoC) is. ${ }^{13}$

A fő fazettát minden esetben a hierarchikus továbbosztás szempontja jelenti, a továbbiak pedig korlátozottan, illetve általánosan közös alosztásokkal fejezhetők ki. Olyan általános kategórialista, amely egységesen, valamennyi osztályra vonatkozóan meghatározná a fazetták kialakítását és alkalmazását, egyelőre nem került kidolgozásra. Ezért, illetve a revízióra vonatkozó dokumentáció egyéb hiányosságai miatt, 2010-ben a szerkesztői bizottság ideiglenesen felfüggesztette a jelentős, az ETO struktúráját nagy mértékben érintő változtatások véghezvitelét addig, amíg a megfelelő FAT keretrendszer kidolgozásra és alkalmazásra nem kerül. ${ }^{14}$

Az ETO elmúlt időszaka ennek ellenére is sok módosítást hozott. Ezeket megvizsgálva az egyes osztályok fentiek szerinti teljes fazettás átalakítása mellett a következö tendenciákat fedezhetjük fel:

- A régi, tudományosan, illetve világnézet szempontjából elavult szerkezetet és fogalomkészletet tartalmazó területek átdolgozása:

o a fogalomkészlet pontosítása,

o a hierarchia korrekciója, ha szükséges,

o hiányzó fogalmak pótlása,

o korábban nem létező fogalmak hozzáadása a rendszerhez.

- A redundancia kiküszöbölése, az enumeráció csökkentése:

o ismétlődő táblázatrészek kiváltása jelzetkombinációval,

o az alosztásokkal kifejezhető tulajdonságok alapján meghatározott hierarchiák szintetikus jelzetekre cserélése.

- Egységesebb, kiegyensúlyozottabb hierarchia kialakítása:

o azonos fogalmi szinten lévő jelzetek azonos hierarchiaszintre hozása a táblázatokban is,

o a hierarchiaszint korrigálása, ha az nem tükrözi a fogalom jelentőségét az osztályon belül,

${ }^{12}$ Gnoli, Claudio: The UDC Philosophy Revision: First Report. = Extensions and Corrections to the UDC 31. 2009. 25-31. p.

${ }^{13}$ Data Elements in UDC MRF Exports. http://www.udcc.org/files/udc_data_elements_mrf11. pdf (2019. szeptember 22.)

${ }^{14}$ Slavic, Aida - Davies, Sylvie: i. m. 
o szülőfogalmak létrehozása, hogy az integrációs szintek egységesek legyenek.

- A gépesítés megkönnyítése a jelzetelemek azonosítását megnehezítő szintaktikai megoldások felszámolásával:

o számvégződéses alosztások felszámolása,

o párhuzamos továbbosztások viszonyításra cserélése (jelöléstani megfontolásból),

o az aposztrófos jelzetszintézis kiváltása,

o egyes enumerációk aposztrófos korlátozottan közös vagy külső forrásból származó jelzetre cserélése.

- Végül a szemantikai (lásd, lásd még) kapcsolatok is folyamatos felülvizsgálat és karbantartás tárgyát képezik.

\section{Az ETO legfontosabb változásai 2001 óta}

Ahogy korábban már szó volt róla, a 2005. évi magyar nyelvủ nyomtatott ETOkiadás a 2000-ben kiadott Extensions and Corrections 22 (EC 22) anyagát tartalmazza. Azóta az Extensions and Correctionsnek 15 kötete jelent meg, ${ }^{15} \mathrm{a}$ bennük közölt módosítások több ezer osztályt érintettek kisebb-nagyobb mértékben. Az alábbi lista azokat a tudományos igényü átszervezéseket tartalmazza, amelyekben nagyobb korrekcióval egy vagy több (fó-)osztály anyagát a fenti céloknak megfelelően szisztematikusan módosították (zárójelben a változást közlő Extensions and Corrections kötet száma szerepel). ${ }^{16171819}$

Általánosan közös alosztások:

- Alosztási jelek

o Leírások pontosítása (EC 23 2001, EC 24 2002).

- $\quad=\ldots$ Nyelvi általánosan közös alosztások

o =4 Afrikai őslakosok nyelvei. Teljes revízió (EC 34-35 20122013).

o $=8$ Amerikai őslakosok nyelvei. Teljes revízió (EC 30 2008, EC 31 2009, EC 34-35 2012-2013).

- (...) Földrajzi hely szerinti általánosan közös alosztások. Teljes táblázatok kiadása (EC 27 2005).

o Geopolitikai változások követése.

${ }^{15}$ Extensions \& Corrections to the UDC. 2019. http://www.udcc.org/index.php/site/page? view $=$ ec (2019. szeptember 18.)

${ }^{16}$ Extensions \& Corrections to the UDC. 2019.: i. m.

${ }^{17}$ Major changes to the UDC 1993-2013. http://www.udcc.org/index.php/site/page?view= major_revisions (2019. szeptember 18.)

${ }^{18}$ Extensions \& Corrections to the UDC, 34-35 (2012-2013)

${ }^{19}$ Extensions \& Corrections to the UDC, 36-37 (2014-2015) 
- -02 Tulajdonságok általánosan közös alosztásai. Új tulajdonságok.

o -026.513 Látható fény (színek). Új osztály (EC 25 2003).

- -04 Kapcsolatokat, folyamatokat, müveleteket jelölő általánosan közös alosztások. Bevezetés (EC 25 2003).

o -042 Fázisrelációk. Új osztály (EC 27 2005).

- -05 Személyek szerinti általánosan közös alosztások. Kiterjesztés a teljes ETO-ra (EC 25 2003).

o -055.1/.4 LMBTQ emberekre vonatkozó jelzetek revíziója (EC 36-37 2014-2015).

Főtáblázatok:

- 0 Általános művek. Ismeretek. Információ

o 004 Informatika. Új fogalmak.

o 005 Menedzsment. Új osztály (EC 23 2001).

o 07 Média. Új osztály (EC 34-35 2012-2013).

- 2 Vallás. Teológia

o 24 Buddhizmus. Revízió (EC 23 2001).

o 26 Judaizmus. Revízió (EC 34-35 2012-2013).

o 271 Keresztény keleti egyház. Revízió (EC 24 2002).

o 28 Iszlám. Revízió (EC 28 2006).

- 3 Társadalomtudományok

o 304 Szociális kérdés általában

- 304.35 Wellbeing-wellness mint életstílus. Új osztály (EC 36-37 2014-2015)

o 314 Demográfia. Revízió (EC 24 2002)

o 316 Szociológia. Új fogalmak $(2002,2006)$. Revízió (EC 34-35 2012-2013).

o 33 Gazdaság. FAT-revízió (2005). Új fogalmak (EC 34-35 2012-2013, EC 36-37 2014-2015).

o 37 Oktatás. Revízió (EC 26 2004). Új alosztások (EC 36-37 2014-2015).

- 5 Matematika. Természettudományok

o 51 Matematika

- 510 A matematika alapjai. FAT-revízió (EC 28 2006).

- 512 Algebra. FAT-revízió (EC 28 2006).

512.7 Kommutatív algebra és algebrai geometria. Revízió és kiterjesztés (EC 36-37 20142015).

- 517 Analízis. FAT revízió (EC 28 2006).

o 53 Fizika. Revízió (EC 25 2003, EC 32 2010). 
- 530. A fizika alapvető elvei. Revízió (EC 28 2006).

- 535 Fénytan. Új korlátozottan közös alosztás a látható fényre (EC 25 2003). Revízió (EC 28 2006).

- 536. Hőtan. Revízió (EC 28 2006). Új korlátozottan közös alosztások (EC 36-37 2014-2015).

- 538 Kondenzált (cseppfolyós és szilárd halmazállapotú) anyag fizikája. Revízió (EC 28 2006).

- 539 Anyagszerkezet. Revízió (EC 28 2006).

o 54 Kémia

- 546.798.37 Szupernehéz szintetikus elemek. Új osztály (EC 36-37 2014-2015).

- 546.91 Drágakőismeret. Gemmológia Új osztály (EC 36-37 2014-2015).

o 56 Paleontológia. Revízió (EC 33 2011, EC 36-37 2014-2015).

o 582 Növényrendszertan. Teljes revízió (EC 33 2011).

o 592/599 Állatrendszertan. Teljes revízió (EC 32 2010, EC 33 2011, EC 36-37 2014-2015).

- 6 Alkalmazott tudományok. Orvostudomány

o 60 Biotechnológia. Új osztály (EC 24 2002).

o 61 Orvostudományok

- 613.88/.89 Szexológia. Szexuális identitás és orientáció. A szexualitás gyakorlata. Teljes revízió (EC 34-35 2012-2013).

- 614.44 Fertőző betegségekkel kapcsolatos intézkedések. Revízió (EC 36-37 2014-2015).

- 615.849.1 Sugárterápia. Revízió (EC 34-35 20122013).

o 62 Mérnöki tudományok

- 621 Mechanikai tervezés. Revízió (EC 25 2003).

- 626/67 Vízépítés. Korlátozottan közös alosztások revíziója (EC 36-37 2014-2015).

- 629 Jármütechnika. Revízió (EC 25 2003)

- 629.05 Jármüvek irányító- és szabályzórendszerei. Revízió (EC 34-35 2012-2013, EC 36-37 2014-2015).

o 63 Mezőgazdaság. Erdőgazdálkodás. Állattenyésztés. Vadászat. Halászat.

- 630 Új példák.

o 64 Háztartás. Nagy mértékü revízió (EC 27 2005).

o 65/68 feldolgozóipar, kereskedelem és kézmüvesség. Új jelzet (EC 34-35 2012-2013) 
- 65 Ipari, kereskedelmi, közlekedési és távközlési üzemek szervezése és vezetése

656 Postai és szállítási szolgáltatások. Revízió (EC 25 2003).

- 68 Továbbfeldolgozó iparok. Teljes osztály revíziója (EC 25 2003)

681.13 Árusító automaták. Hierarchia felszámolása (EC 26 2004).

681.8 Müszaki akusztika. Revízió (EC 27 2005).

684 Bútorok. Revízió (EC 27 2005).

- 7 Mủvészetek. Kikapcsolódás. Sport

o 72 Építészet. FAT-revízió (EC 25 2003).

o 77 Fényképezés. Kisebb revízió (EC 24 2002). Új jelzetek (EC 34-35 2012-2013).

o 78 Zene. Hangszerek átszervezése (EC 25 2003).

o 793.21 Cirkuszok. Bemutatók. Menazsériák. Előadások. Utazó vásárok és show-k. Áthelyezve a 791 Filmszínház. Mozi. Film alól (EC 34-35 2012-2013).

o 795 Elektronikus játékok. Új jelzet (EC 34-35 2012-2013).

- 8 Nyelvek. Nyelvtudomány. Irodalom

o Korlátozottan közös alosztások revíziója (EC 34-35 2012-2013, EC 36-37 2014-2015).

o 821 Egyes nyelvek irodalma. Kiterjesztés (EC 30 2008).

- 9 Régészet. Földrajz. Életrajz. Történelem

o 94 Egyes országok történelme. Kiterjesztés, részletes kombinációs példák.

\section{Példák a különböző típusú változásokra}

A jelen fejezet néhány olyan példákat tartalmaz, amelyek jól szemléltetik a változások jellegét.

\section{A hierarchia korrigálása}

A földrajzi alosztások több példát is szolgáltatnak a hierarchiában bekövetkezett változásokra.

A legfontosabb és legjelentősebb változás ezekben az alosztásokban a teljes, a korábbi bővített ETO-kiadásoknak megfelelő mélységü táblázatok kiadása, amelyek 2005-ben (EC 27) jelentek meg az Extensions and Corrections mellékleteként. Jelenleg az ETO a világ valamennyi országának összes közigazgatási egységét tartalmazza a magyar megyéknek megfelelő szintig (egy adott ország 
közigazgatási rendszerét az ETO-számához tartozó információs megjegyzés tartalmazza), a leírásokban valamennyi ország és közigazgatási egység neve megjelenik az ország hivatalos nyelvén, nyelvein is (latin átírással).

A 2012-2013 évi kiadás (EC 34-35) számos módosulást hozott az alosztás hierarchiájában. A jelzethasználat következetesebbé tételét célozza, hogy valamennyi országnak a saját hierarchiaszintjén pontosan egy jelzete van. A korábban Dél-Afrikát (682.1/687) és Mexikót jelölő (721/727) jelzetek átmozgatásra kerültek a (680), illetve (720) alá. Oroszország és a Szovjetunió esetében is megszünt az automatikus feldolgozást megnehezítö összekötéses jelzetalkotás, a jövőben az ország egészére a (471), illetve (47) jelzetet kell alkalmazni (az utóbbi változás az EC 36-37-ben jelent meg, együtt a következő fejezetben tárgyalt módosításokkal).

A skandináv országoknál a közigazgatási egységek, illetve a történelmi tartományok esetében megszünt a csillagos jelzetképzés - pl. Finnország esetében $(480 * 1 / 9)$-, immár ezek a jelzetek is megjelennek a hierarchiában. A Déli Indiai-óceán szigetei a (699.1/.17) alól át lettek helyezve a (992.1) alá a Déli Indiai-óceán szubantarktikus szigetei néven, valamint önálló jelzetekkel bekerültek a rendszerbe az európai arktikus szigetek (984), Grönland körzetei (988.1/.5), a Déli-sarkvidék szigetei (992), az antarktiszi területek és a Délisark régiói (995) is.

\section{A táblázatok aktualizálása}

Elsősorban a közelmúlt geopolitikai változásai miatt a földrajzi alosztások lehetőséget adnak annak a demonstrálására is, hogy az ETO hogyan alkalmazkodik a változásokhoz. Ilyen változás volt például Dél-Szudán 2011-es függetlenné válása, amely után a vonatkozó rész az alábbiak szerint módosult (EC 36-37 2014-2015):

(624) Szudán (2011-ig) SN: A korábbi Szudáni Köztársaságra vonatkozó művek osztályozandók ide, a 2011-es felbomlásig

(624.1) Észak-Szudán

(624.11) Darfúr

(624.12) Észak-Szudán

(624.15) Kordofan IN: A korábbi Nyugat-Kordofán (2005-ben megszünt és kettévált Észak- és Dél-Kordofán államokra)

(624.15) Al-Foulah IN: A korábbi Nyugat-Kordofán egykori fővárosa (2005-ben megszünt) (2012-2013 EC 34-35)

(624.24) Abyei tartomány (vitatott terület)

(624.4) Dél-Szudán. Dél-Szudáni Köztársaság 
Valamivel régebbi adósság volt a brit fennhatóság alól 1983-ban függetlenedő Saint Kitts és Nevis helyzetének rendezése. Az ország ezentúl a korábbi, a Brit Virgin-szigetek alatti szám helyett a (729.73) jelzettel van kifejezve (2012-2013 EC 34-35).

Az elmúlt időszak egyik legtöbbet vitatott és hivatkozott változása a Krím és Kelet-Ukrajna státuszának megváltozása. Ehhez az ETO az alábbi módon igazodott (2014-2015 EC 36-37):

(477) Ukrajna

(477.54/.62) Kelet-Ukrajna

(477.54) Harkovi régió

(477.6) Donyeck Bazin (a Ronban-régió ukrajnai részei)

(477.61) Luhanszki régió. SN: 2014 óta független, az ENSZ által el nem ismert terület (2018-as helyzet)

(477.62) Donyecki régió. SN: 2014 óta független, az ENSZ által el nem ismert terület (2018-as helyzet)

(477.75) Krími Független Köztársaság. SN: 2014 óta független, az ENSZ által nem teljesen elismert terület (2018-as helyzet).

A kétezres években létrejött oroszországi határterületekkel ${ }^{20}$ kapcsolatos közigazgatási változások ugyanebben az ETO-verzióban lettek publikálva. ${ }^{21}$

\section{Osztályok teljes revíziója}

Egy adott osztálynak a tudomány fejlődését követő újraépítésére példa az öslénytan, illetve a rendszertan osztályainak átszervezése, amely az 56 Őslénytan és 57/59 Biológia teljes revíziójának részeként valósult meg. ${ }^{22}$

A növényrendszertani osztály átírására azért volt szükség, mert az a napjainkra elavulttá váló Cronquist-féle rendszeren alapult. A munka, melynek eredménye 2011-ben (EC 34) jelent meg, a genetikailag igazolt Angiosperm Phylogeny Groupot vette alapul, így teljes mértékben megfelel napjaink tudományos igényeinek. ${ }^{23}$

Az ETO állatrendszertana a kezdetektől a klasszikus, Carl von Linné munkáján alapuló rendszertanra épült, amely jelenleg is a legszélesebb körben elfogadott (bár sokat vitatott) rendszerezés. Elsődleges alternatívája a Willi Hennig nevéhez

\footnotetext{
${ }^{20}$ Oroszország közigazgatási beosztása. https://hu.wikipedia.org/wiki/Oroszorsz\%C3\%A1g _k\%C3\%B6zigazgat\%C3\%A1si_beoszt $\% \mathrm{C} 3 \% \mathrm{~A} 1$ sa (2019. szeptember 18.)

${ }^{21}$ Érdekesség, hogy ez hivatalosan bár a 2014-2015. évi ETO verzió, a késedelmes kiadás miatt hivatalosan a 2018. évi állapotokat rögzíti.

${ }^{22}$ Civallero, Edgardo: UDC Biology Revision Project: Reports on Stages 3-6. = Extensions and Corrections to the UDC 36-37 (2014-2015). 2019. 59-73. p.

${ }^{23}$ Civallero, Edgardo: UDC Biology Revision Project: Second Stage: Class 58 Botany. = Extensions and Corrections to the UDC 33. 2011.37-40. p.
} 
füződő kladisztika filogenetikus rendszer, amely az élőlényeket kládokba (ágakba), azokat pedig kladogramba (fába) sorolja, a genetikai leszármazás szerint. Ugyan ez a rendszer még nem teljes, de folyamatosan fejlödik, és a használata is egyre szélesebb körben elfogadott.

A zoológia revíziója mögött meghúzódó elképzelés szerint az új rendszer egyaránt használható a Linné-féle és a kladisztikus rendszertan szerinti osztályozásra. Az átalakítást követően a hierarchiában a család lesz a legalacsonyabb szint, a „genus” és „faj” a „beleértve” mezőben jelennek meg. Az osztályok nevei kizárólag a tudományos megnevezéseket tartalmazzák, az egyes fajok hétköznapi nevei szintén a „beleértve” mezőbe kerültek, s ettől csak néhány különösen indokolt esetben van eltérés. Amennyiben egy tudományosan nem indokolt taxon a használat elterjedtsége miatt mégis bekerült a rendszerbe, akkor azt külön is jelzik. ${ }^{24}$

Fontos változás, hogy a kihalt fajok az öslénytanból átkerültek a rendszertani részbe (a leírásban „kihalt” megjegyzéssel), így azok kifejezésére, amenynyiben a tárgyalásmód nem őslénytani, az 56 Paleontológia alatt párhuzamos továbbképzéssel képzett jelzetek helyett ezentúl az 58/59 alatti jelzetüket kell használni. Paleontológiai tárgyalásmód esetén az 56 használandó, de párhuzamos továbbosztás helyett kettőspontos viszonyítást kell használni az 58/59 alatti jelzetekkel (pl. 561.29 helyett 56:582.29 Zuzmók paleontológiája vagy 56:593.4 Fosszilis szivacsok). ${ }^{2526}$

A revízió első lépcsőjeként az 597/599 Gerincesek átdolgozása lett kész (2010 EC 32), ezt követte az 582 Szisztematikus botanika (2011 EC 33). A maradék osztályok felújított verziója a 2014-2015. évi Extensions and Correctionsben (36-37) jelent meg. A mikroorganizmusok, színesmoszatok és vírusok átdolgozott osztályaira egyelőre csak javaslat jelent meg, végleges formájukat a tervek szerint a következő ETO-kiadás fogja tartalmazni. ${ }^{27}$

\section{Átfogó revízió}

A tudományok, a világkép, a kultúra módosulásai időnként átfogó, a táblázatok több helyét érintő módosításokat is szükségessé tesznek. Az alábbiakban erre láthatunk példát.

-05 Személyek szerinti általánosan közös alosztások (EC 34-35 2012-2013) -055.1/.4 Személyek nem, szexuális orientáció, szexuális identitás és gender szerint (új jelzet a -055.1/.3 Személyek nem (gender) szerint leváltására).

${ }^{24}$ Civallero, Edgardo: UDC Biology Revision Project: First Stage: Class 59 Vertebrates. Extensions and Corrections to the UDC 32. 2010. 9-20. p.

${ }^{25}$ Civallero, Edgardo: UDC Biology Revision Project: SecondStage: Class 58 Botany: i. m.

${ }^{26}$ Civallero, Edgardo: UDC Biology Revision Project: Reports on Stages 3-6.: i. m.

${ }^{27}$ Civallero, Edgardo: UDC Biology Revision Project: Reports on Stages 3-6.: i. m. 
-055.29 Interszex személy

-055.3 Személyek szexuális orientáció szerint

-055.32 Heteroszexuális

-055.34 Homoszexuális. Meleg

-055.36 Biszexuális

-055.4 Személyek szexuális identitás és gender szerint (új jelzetek)

-055.41 Ciszgender személyek. Ciszszexuálisok

-055.42 Androgynek. Transzgenderek. Genderqueer / nem bináris nemi identitások

-055.421 Agenderek. Gender nélküliek

-055.422 Bigenderek. Trigenderek. Pangenderek

-055.423 Transzszexuálisok

-055.423.2 Eunuchok

-055.425 Harmadik, negyedik stb. gender

316 Szociológia

316.367.7 Homoszexuális kapcsolatok. Meleg és leszbikus kapcsolatok (módosult jelzet).

316.811.115 Azonos nemüek házassága. Melegházasság (új jelzet, bevezetve 2002 EC 24).

612.6 Szaporodás. Növekedés és fejlődés

612.6.058 Interszex állapotok. Interszex biológia. Beleértve: A standard emberi kariotípus variációi (atipikus szexuális kromoszómák), nem szokványos nemi hormonok, különböző interszex feltételek (pl. androgéninszenzitivitás szindróma), nem egyértelmủ külső nemi szervek. Leírás: Minden ide osztályozandó, amire korábban a (tudományosan elavult) hermafroditizmus szó volt használatos (módosult jelzet).

\section{Korábban nem létező fogalmak}

A tudomány és technika gyorsuló fejlődése, a világnézet változásai nemcsak a korábbi fogalmak pontosítását, hanem teljesen újak bekerülését is szükségessé teszik. Az alábbi lista ilyen fogalmakra tartalmaz példákat a legkülönbözőbb területekröl.

004 Számítástechnika

004.411 Szoftverfejlesztési metodológiák (2012-2013 EC 34-35)

004.774.25 Kapcsolt adat (Linked Data) (2012-2013 EC 34-35)

004.774.1 Közösségi háló. Részvételen alapuló web. Kombinációs példa: 004.774.1FB Facebook (2012-2013 EC 34-35)

004.6 Adattárak. Kombinációs példa: 004.6-022.59 Big Data (2012-2013 EC 34-35)

004.382.73/.77 Hordozható számítógépek (2014-2015 EC 36-37) 
004.382.732 Ultra hordozható gépek, subnotebookok, mini notebookok 004.382.74 Pen computerek. Tabletek.

004.382.741 Pen computerek

004.382.742 Tabletek SN: Mobil internet eszközök (MID) is

004.382.745 Okostelefonok SN: úgy osztályozandók, mint a telefonok a 621.395.721.5 alatt

004.382.77 Hordozható adatterminálok

004.76 Felhő alapú szolgáltatások, cloudcomputing (EC 36-37, 2014-2015)

004.761 Platformszolgáltatás. Platform as a Service (PaaS)

004.762 Szoftverszolgáltatás. Software as a Service (SaaS)

004.763 Infrastruktúra szolgáltatás. Infrastructureas a Service (Iaas). Kombinációs példák: 004.763:004.383.2 Felhö alapú szerver szolgáltató. Cloud server provider. 004.763AWS Amazon web services

004.764 Szerver nélküli felhöszolgáltatás. Beleértve: Functionas a Service10 004.765 Mobil háttér szolgáltatás. Mobile Backend as a Service (MbaaS)

004.773.4 Üzenetküldö alkalmazások. Webes telefonálás. Broadband telefonálás. VoIP

004.96 Videó játék tervezés (EC 36-37, 2014-2015)

02 Könyvtárak. Könyvtártan

025.355 Online Elérésü Publikus Katalógusok (OPAC-ok). Kombinációs példák: 025.355:004.5 OPAC-interfész. 025.355:025.4.03 Keresö technikák. 025.355:077 Internetes és web OPAC-ok (új példa, EC 34-35, 2012-2013)

304 Életút

304.35 Wellbeing-wellness mint életstílus (2014-2015 EC 36-37)

33 Gazdaság

336.71 Bankolás. Kombinációs példa: 336.71:077 Internetes bankolás (2012-2013 EC 34-35)

336.79 Financiális szolgáltatások, pénztranszfer szolgáltatások

336.792 Person-to-person pénztranszfer szolgáltatások EoC: 336.792WU Western Union

336.794 Online fizetési szolgáltatások. Kombinációs példa: 336.794PP PayPal

37 Oktatás

37.011.2 Írástudás. Kompetenciák. Képességek (2014-2015 EC 36-37) 
37.011.22 Írástudás (tágabbértelemben). Kombinációs példák: 00:37.011.22 Információs írástudás. 004:37.011.2 Számitógépes irástudás. 077:37.011.2 Internetes irástudás

37.011.25 Írástudás (szükebb értelemben)

37.091 Oktatási intézmények szervezése (2004 EC 26)

37.091.267 Diákokról tárolt adatok. Személyi dossziék és listák (2014-2015 EC 36-37)

54 Kémia

546.798.37 Szupernehéz szintetikus elemek 110 vagy magasabb rendszámmal (2014-2015 EC 36-37) 28

629 Jármütechnika

629.014.9 Vezetö nélküli jármüvek (2012-2013 EC 34-35)

664 Élelmiszerek előállítása

664.665 Kenyérhez hasonló termékek különleges célokkal vagy diétás célokra. Kombinációs példa: 664.665:664.236-021.146.6 Gluténmentes kenyér (2014-2015 EC 36-37)

795 Elektronikus játékok (2014-2015 EC 36-37)

\section{FAT-revízió}

Az 51 Matematika osztály 2006. évi (fazettás) revíziója az 510 A matematika alapjai, 512 Algebra és 517 Analízis osztályokat érintette. Az utóbbiból származik a következő példa a redundancia korlátozottan közös alosztásokkal való feloldására. ${ }^{29}$

A kiinduló probléma az volt, hogy miközben az osztály fö fazettáját az egyenletek típusa jelenti, ugyanebben a hierarchiába bekerültek olyan általános fogalmak és problémák, amelyek valójában bármelyik egyenlettípussal kapcsolatban használhatók. Ezért ezek a terület felülvizsgálatát követő pontosítás és bövítés után ki lettek szervezve kötőjeles korlátozottan közös alosztásokba, melyek a fö fazetta szerinti hierarchia bármelyik elemével együtt használhatók.

517.95 Parciális differenciálegyenletek. AN: Az egyes problémákhoz és eljárásokhoz 1. 517.95-2/-8

${ }^{28}$ Az osztályon belül az egyes elemeknek önálló jelzetük van a Darmstadiumtól (vegyjele Ds, rendszáma 110, jelzete 546.798.370) az Oganessonig (Og, 118, 546.798.378).

${ }^{29}$ Barátné Hajdu Ágnes: Dynamism of Knowledge Organization, particularly its relation to UDC. $=20$ Añosdel Capítulo Español de ISKO. Actasdel X Congreso ISKO Capítulo Español (Ferrol, 2011). Universidade da Coruña (España). 2012. 337-351. p. 
517.95-1 Általános jellemzők

517.95-2 A parciális differenciálegyenletek és egyenletrendszerek általános elmélete

517.95-21 Lokális és globális megoldhatósági problémák (lokális és globális egyértelmüségi tételek)

517.95-22 Alapvető megoldások

517.95-23 Geometriai elmélet. Karakterisztikák. Transzformációk

517.95-24 Kvalitatív elmélet

517.95-25 Analitikus módszerek. Szingularitások

517.95-26 Variációs módszerek

517.95-27 Mikrolokális módszerek

517.95-28 Topológiai módszerek

517.95-29 Az általános elmélet egyéb aspektusai

517.95-4 Cauchy-probléma

517.95-42 Jól felállított elmélet

517.95-44 Félcsoportok a Cauchy-problémához kapcsolódóan

517.95-48 A megoldások aszimptotikus viselkedése

517.95-6 Kezdeti érték probléma

517.95-8 Peremérték probléma

\section{Az enumeráció felszámolása}

Olyan esetekben, amikor a hierarchiában szereplő fogalmak kifejezhetők más helyeken található fogalmakkal, a hierarchia felszámolható és helyettesíthetö a jelzetalkotás módjára vonatkozó instrukciókkal, illetve kombinációs példákkal. Ilyen esetekben korábban az ETO-ra jellemző volt a párhuzamos továbbosztás alkalmazása, tehát a táblázat egy másik pontján (szélsőséges esetekben az ETO valamennyi főtáblázatában) kifejezett hierarchia alkalmazása egy adott osztály alatt. Az ilyen továbbosztás hátránya, hogy többértelmü jelzetek is létrejöhetnek $^{30}$, illetve az, hogy a jelzet alkotórészei automatikusan nem azonosíthatók. Ezért ezeket a megoldásokat a táblázatok legtöbb helyén a kettőspontos viszonyítás váltotta fel, és többnyire az újonnan felszámolt enumerációk esetében is ez a megoldás került alkalmazásra.

Egyik legáltalánosabb eset, amikor egy adott fogalomból a táblázatok szinte tetszőleges helyéről származó jelzetek kapcsolásával képezhető értelmes és használható jelzet. Ennek tipikus példája az építészet, melynek fö fazettáját az épületek célja, funkciója képezi. A 2003-ban publikált átszervezés (EC 25) előtt az osztályban mindenütt részletesen kifejtett hierarchiát találhattunk, amelyben feladatuk szerint csoportosítva, önálló jelzettel szerepelt számos épülettípus. Ez egyfelől redundáns megközelítést jelentett, másfelől az épületek a céljuk, felhasz-

\footnotetext{
${ }^{30}$ Mándy Gábor: Régi ETO, új ETO. = Könyvtári Figyelö, 57. évf. 2011. 2. sz. 317-332. p.
} 
nálóik szerint nem voltak visszakereshetők, csakis az építészet irányából. Ezért a revízió során a hierarchia alsóbb szintjeit számos helyen eltörölték, helyettük a kettőspontos viszonyítás alkalmazandó. Az osztályozás és az átállás megkönnyítése érdekében valamennyi korábbi osztálynak megfelelő kombinált jelzet bekerült a kombinációs példák közé, ahogy azt a következő példán láthatjuk:

725.1 Középületek. Törvényhozási épületek. Közszolgálati épületek. Közhasznú épületek

725.11 Parlamenti épületek

725.127 Konzulátusok

725.161 Postahivatalok

A változtatás után:

725.1 Középületek. Törvényhozási épületek. Közszolgálati épületek. Közhasznú épületek. Kombinációs példák: 725.1:328.1 Parlamenti épületek. 725.1:341.81 Konzulátusok. 725.1:656.815.3 Postahivatalok

Az is gyakori, hogy a hierarchia leszükíti a kombinációs lehetőségeket, de a táblázatokban nem szerepel olyan osztály, amivel kiváltható lenne (például mert elméletileg tetszőleges egész szám szóba jöhet). Ilyen esetekben kézenfekvő a külső forrásból származó alosztás alkalmazása, nemcsak a lehetőségek kiszélesítése, hanem a jelzetelemek automatikus felismerhetösége miatt is. Az ilyen típusú módosulások egyik friss példája az atlétikai több próbák átalakítása:

Korábbi jelzetek:

796.093.61/.62 Atlétikai ötpróbák

796.093.615 Ötpróba

796.093.62 Tízpróba

796.093.64 Összetett versenyek több sportág versenyszámaiból

796.093.642 Két sportág versenyszámaiból

796.093.643 Három sportág versenyszámaiból

796.093.645 Öt sportág versenyszámaiból

796.093.645.1 Modern öttusa

A változtatás után:

796.093.61 Összetett versenyek egy sportág versenyszámaiból. Kombinációs példák: 796.093.61*10 Tízpróba. 796.093.61*5 Ötpróba

796.42.093.61 Összetett atlétikai versenyek

796.093.64 Összetett versenyek több sportág versenyszámaiból. Kombinációs példák: 796.093.64*2 Két sportág számaiból. 796.093.64*3 Három sportág számaiból. Triatlon. 796.093.61*5 Öt sportág számaiból. 796.093.64*5"654" Modern öttusa 


\section{Befejezés}

A múltban az ETO-t számos kritika érte elavult, a 19. században gyökerező nyugati szemlélete és tudományfelosztása, a hierarchia egyenetlensége és következetlensége, valamint a szintaktikai relációk többértelmüsége és nehéz automatizálhatósága miatt. Tanulmányomban mindenekelőtt szerettem volna bemutatni azokat a törekvéseket és erőfeszítéseket, melyeknek célja az ismert problémák lehető leghatékonyabb felszámolása, illetve azt a megújult fogalomkészletet, melynek jelentős része immár alkalmas a legújabb és legmodernebb témák kifejezésére is. Ezek alapján az osztályozást jelen formájában már bátran minősíthetjük a 21. század követelményeinek is megfelelő, releváns tartalmi feltáró eszköznek. Ennek az eszköznek a hatékony kihasználását teszi majd lehetővé az új magyar fordítás, amely remélhetőleg minél előbb elkészül és rendelkezésre áll. Az érdeklődők addig is elérhetik az ETO mindenkori legújabb (tehát a cikkben tárgyalt módosításokat is tartalmazó) anyagát angol nyelven, önálló kereső és böngészö felülettel az ETO Konzorcium által gondozott Online ETO (UDC Online) oldalon keresztül, díjfizetés ellenében. ${ }^{31}$

\section{Rezümé}

Az elmúlt csaknem százhúsz év során a mesterséges nyelvủ tartalmi feltáró, úgynevezett osztályozási rendszerek közül az Egyetemes Tizedes Osztályozás (ETO) használata és oktatása terjedt el a legszélesebb körben a magyar könyvtári rendszer különbözö szintjein. Az osztályozási rendszer legutóbbi magyar nyelvü, a tartalmát tekintve teljes egészében az ETO 2000-ben közreadott központi adatbázisán alapuló kiadása hosszas és gondos fordítási és szerkesztési munka eredményeként 2005-ben látott napvilágot. Az ETO utóbbi harminc éve a rendszer tudományos alapokon nyugvó, folyamatos, öszszehangolt és tudatos fejlesztésével telt. Az átszervezések kimondott célja az egyes tudomány- és tudásterületek egyre gyorsuló változásaival való szükségszerủ lépéstartás megkísérlése mellett az osztályozás nyelvének könnyebben automatizálhatóvá tétele volt. A fejlödés első évtizedének eredményeivel az imént említett magyar kiadásban is találkozhattunk. Az elmúlt húsz év számos további újitást hozott, melyek áttekintését különösen aktuálissá teszi az Országos Széchényi Könyvtár csatlakozása az ETO-t gondozó konzorciumhoz, illetve az új magyar ETO-fordítás előkészületeinek indulása.

\section{The Twenty Years of Universal Decimal Classification}

Since the beginning of the twentieth century Universal Decimal Classification (UDC) has become the predominant classification system employed at every level of the Hungarian library network. The most recent Hungarian edition of the schema, containing the material of the UDC version released in 2000, was published in 2005. The last thirty years have

${ }^{31}$ http://udc-hub.com (2019. október 1.) 
seen a continuous, coordinated and scientifically based revision of the system. The explicit purpose of the modifications was, aside from following the accelerated changes of science and other knowledge areas, to render the schema's grammar and vocabulary easier to automate. Although the results of the first period of refactoring appear in the aforementioned Hungarian edition, many further changes have been published in the last twenty years. Since the National Széchényi Library joined the UDC Consortium and the preparation of the new Hungarian online edition began, reviewing the recent changes of UDC has become particularly pertinent.

PirOs ATTILA szenior szoftverfejlesztő Nebu Hungary Kft. ORCID: 0000-0003-2338-6009 